\title{
Has the awareness of orthopedic surgeons on osteoporosis been increased in the past decade?
}

\author{
Ortopedik cerrahların osteoporozdaki farkındalığı geçen on yılda artı mı? \\ O. Şahap Atik, MD. \\ Department of Orthopedics and Traumatology, Medical Faculty of Gazi University, Ankara, Turkey
}

Yes. Orthopedic surgeons are more aware of surgical treatment of osteoporotic fractures in the past decade; however, this is not the same for the medical treatment. ${ }^{[1]}$

In Turkey, the majority of patients presenting with osteoporotic hip and vertebra fractures are underevaluated and undertreated for the prevention of secondary fractures. ${ }^{[2]}$ The cumulative incidence of secondary hip fractures has been reported to be 9\% in the Netherlands. ${ }^{[3]}$ The relatively high risk of sustaining secondary hip fractures highlights the importance of secondary prevention in patients with a prior wrist or vertebral fracture.

The World Health Organization (WHO) developed the Fracture Risk Assessment Tool (FRAX), a tool used for the osteoporotic fracture risk assessment. ${ }^{[4]}$ However, we still believe that the FRAX tool has serious limitations for some countries. ${ }^{[5]}$

Furthermore, the definition of osteoporosis based on $\mathrm{T}$-score on bone mineral density measurement is no longer sufficient. ${ }^{[6]}$ Therefore, the following question should be answered: Which subgroups of patients with low-energy fractures are eligible to undergo anti-osteoporotic drug therapy? The answer is simple:
- If the patient has low-energy distal radius fracture, be alert to spinal or hip fractures,

- If the patient has low-energy spinal or hip fracture, be aware of further spinal or secondary hip fractures, and

- Start anti-osteoporotic drug therapy!

\section{REFERENCES}

1. Moradi R, Atik OS. Are orthopedic surgeons more aware of medical treatment of osteoporotic fractures in the last decade?. [Article in Turkish] Eklem Hastalik Cerrahisi 2014;25:80-4.

2. Güngör HR, Ok N, Akkaya S, Kiter E. Orthopedic surgeons' view for the prevention of osteoporotic secondary fractures: a survey. [Article in Turkish] Eklem Hastalik Cerrahisi 2014;25:148-53.

3. Burgers PT, Zielinski SM, Mailuhu AK, Heetveld MJ, Verhofstad $\mathrm{MH}$, Roukema GR, et al. Cumulative incidence and treatment of non-simultaneous bilateral femoral neck fractures in a cohort of one thousand two hundred and fifty patients. Int Orthop 2014;38:2335-42.

4. Available from: http://www.shef.ac.uk/FRAX/tool.jsp

5. Atik OŞ. How valid FRAX is in different countries? Eklem Hastalik Cerrahisi 2013;24:63.

6. Gül O, Atik OS, Erdoğan D, Göktaş G, Elmas C. Transmission and scanning electron microscopy confirm that bone microstructure is similar in osteopenic and osteoporotic patients. Eklem Hastalik Cerrahisi 2013;24:126-32.

\footnotetext{
- Correspondence: O. Şahap Atik, MD. Gazi Üniversitesi Tıp Fakültesi Ortopedi ve Travmatoloji Anabilim Dalı, 06500 Beşevler, Ankara, Turkey. Tel: +90 312 - 2025528 Fax: +90 312 - 2129008 e-mail: satikmd@gmail.com
} 